\title{
The Internet as a Space for Anonymous Alcoholics during the SARS-COV-2 (Covid-19) Pandemic
}

\author{
Beata Hoffmann ${ }^{1}$ \& Marek Dudkiewicz ${ }^{2}$ \\ ${ }^{1}$ Institute of Applied Social Sciences, University of Warsaw, Poland \\ ${ }^{2}$ MMD Milanowa S.C., Poland \\ Correspondence: Beata Hoffmann, Institute of Applied Social Sciences, University of Warsaw, Nowy Świat 69, \\ 00-927 Warsaw, Poland
}

Received: May 19, 2021 Accepted: June 23, 2021 Online Published: July 6, 2021

doi:10.5539/gjhs.v13n8p61 URL: https://doi.org/10.5539/gjhs.v13n8p61

\begin{abstract}
Introduction: For over a year, Poland, alongside the entire world, has been facing the SARS-COV-2 (COVID-19 pandemic). This emergency has caused an immense social crisis, affecting especially the individual. The lack of social activity, including direct communication, along severe limitations on public and professional lives, have become a threat to mental health of people in almost all countries of the world. This state can be particularly difficult and dangerous to people with addiction. In the recovery process for alcoholics, a special role is often played by the Alcoholics Anonymous groups.
\end{abstract}

Objectives: Due to the pandemic, meetings of AA groups (as well as other therapeutic groups) have been suspended until further notice. Due to this - due to necessity, not choice - such groups have moved to the online space. This raises a question if internet group meetings can make up for the lack of AA group meetings in physical space.

Methods: The research had an exploratory character. It was conducted between the start of June and the start of July 2020. 225 people participated. The research was conducted using quantitative methods, using a questionnaire designed specifically for this purpose.

Results: The research results indicate that the COVID-19 pandemic affected almost all of our respondents. The way the AA meetings work changed. Compared to live meetings, the frequency of meetings increased, the satisfaction from participation simultaneously decreased. Major flaws of online meetings are seen in the discomfort of respondents: some people stopped attending meetings after they moved to the internet. The positive sides of online meetings mainly had to do with the possibility of meeting and contacting new people living far and with organisational matters. The frequency of attending therapy with specialists/therapists decreased during the pandemic, while the frequency of contact with one's sponsor increased. The overwhelming majority of respondents declared that they did not break abstinence during the pandemic. Those who did were usually people who had spent little time (usually a year, five years at most) in abstinence. The pandemic did not influence subjective appraisal of life quality.

Conclusion: Our research showed that after the pandemic, our respondents would prefer to return to traditional, live AA meetings, organized as they used to be before COVID-19. Online meetings would only serve a useful, but ultimately complementary role.

Keywords: alcoholics anonymous, alcohol addiction, pandemic, SARS-COV-2 (COVID-19), internet self-help groups

\section{Introduction}

The first recorded case of a SARS-COV-2 virus infection had been detected in Poland on the fourth of March, 2020. Between the 14th and the 20th of March, a state of epidemic emergency had been put in place in the country, and since the 20th of March, through an ordinance by the then-Minister of Health Łukasz Szumowski, Poland remains under a state of epidemic.

Doubtlessly, the COVID-19 pandemic has serious effects on most social, demographic and economic processes, in Poland and abroad. A sense of endangerment, together with economic anxiety and compulsory isolation can have 
dangerous consequences for the individual. The lack of social activity, including direct interpersonal communication and participation in public and professional life is one of the leading causes for the deterioration of the psychic condition of people in stricken countries.

As research indicates, "during extreme situations like wars or economic crises, consumption of psychoactive substances, including alcohol, increases dramatically" (Chodkiewicz, 2020). Our present situation is one of an emergency and of unpredictability, with many unknown in the future (Chodkiewicz, 2020). Social isolation, the lack of interpersonal relations, fear of infection, disruption of daily functions and even boredom can compel a person to consume more alcohol than usual. It can also pose a threat to people in the state of abstinence. Excessive alcohol consumption can create psychic ailments such as anxiety and depression, or exacerbate previously extant ones (Pollard et al., 2020). Changes in modes of alcohol consumption are also visible. With the move of life to online social networks, online aperitifs started to occur as a phenomenon of meeting for a drink with family or friends over video sharing software. According to Sarah Johnson, the directory of Kentucky's Landmark Recovery addiction care programme in Louisville, the pandemic has in many ways limited social drinking, while drinking alone is perceived as especially risky (Johnson, 2020). It should be noted that in many countries, including Poland, the alcohol industry, citing losses caused by the closure of hotels, bars and restaurants, as well as by the ban on social events, demands a quick amendment to laws that would enable the retail sale of alcohol over the Internet.

Under the conditions of the pandemic, virtual communication (utilizing technology), appears to be the sole alternative to the traditional "face to face" communication, rendering it necessary to even partially overcome pandemic restrictions.

\section{Objectives}

Aside from professional care, be it stationary or ambulatory, it is vital for addicted persons to participate in self-help group meetings. In the process of recovery for the non-drinking alcoholics, regular contact with such a group and the ability to ask within it for help is key.

Due to the SARS-COV-2 (COVID-19) pandemic, we are dealing with an exceptional and unprecedented situation where Alcoholics Anonymous groups, ubiquitous in physical space, have, out of necessity rather than choice, turned into online groups.

A question arises as to whether such a form of contact is capable of making up for the lack of group participation. Can the internet become the space for the AA movement to flourish? Can aspects of this form of communication find use in traditional self-help practices of the AA? Can such groups become an alternative or a complementary element of recovering for people struggling with alcoholism? This research was intended to answer those questions.

\subsection{Social Support}

Social support is variously defined and described, in accordance with one's preferred analytical framework (Lakey \& Cohen, 2000). In Polish research, the most commonly represented is the model dividing social support into functional and structural (Sęk \& Cieślak, 2011; Kawula, 2005; Włodarczyk, 2016).

Currently, the most commonly researched aspect of social support is how to use it to help in situations of life's stress caused by factors such as illness or serious private, family and professional struggles (e.g. death of a loved one, divorce, unemployment, financial struggles, etc.) (Schwarzer \& Weiner, 1991; Nahid \& Sarkis, 1994). Social support is also investigated from the side of human needs, such as the need for safety, for belonging, or for acceptance. Proponents of such an approach highlight the importance of particular patterns of attachment in the process of establishing social relations. Being in relation to others is, in this understanding, a fundamental prerequisite for an individual's growth (Sęk \& Cieślak, 2011). In this approach, social support isn't limited to assisting in difficult, stress-inducing situations, but is rather seen as a constant factor available to each person, helping adjustment and psychic and mental fitness (Owczarek, 2018).

In spite of the differences in definition and in theory, it is commonly accepted that it is this kind of approach to support that has key influence on proper function of each individual and influences their physical, emotional and mental health (Knoll \& Schwarzer, 2007).

\subsection{Mutual Aid and Self-Help}

We'd like to first note that the terms "mutual aid" (support groups) and self-help (self-help groups) are often used interchangeably, in spite of serious etymological differences between them and their original meaning (BORIS, 2020).

According to Alfred H. Katz and Eugene I. Bender, self-help groups are consensual, small group structures 
directed towards mutual help and achieving a specific goal. They are usually established by people viewing themselves as peers, and focused on fulfilling a shared need, on overcoming a shared deficiency, or struggling against challenges they as blocking desirable social or personal changes (Szmagalski, 1994).

In Zasada pomocniczości - wspieranie działań samopomocowych i samoorganizacyjnych [The Aid Principle Supporting self-help and self-organisation] Andrzej Juros described self-help groups as "a group of people connected through a shared problem, requiring little to none financial investment, meeting principally to find psychic support for particular persons" (Juros, 2003, p. 19).

A definition by Ronald Kessler, created for the use of the National Institute of Mental Help, deserves mention. According to him, self-help groups are "groups organized and directed by people with similar experiences, in order to help and support each other" (Riessman, 1996, p. 887). Notably, Kessler claims that groups which are or were established and directed by doctors, psychologists, social workers or other professionals should not be treated as self-help groups (Riessman, 1996). The dynamically developing self-help movement has, in the past few decades, grown across the globe. The same trend can be seen with regards to internet self-help groups.

According to Susan Sparks, addicted persons utilizing internet self-help groups have access to a round-the-clock contact through email. They are furthermore able to select people they want to be in touch with, can maintain contact with any chosen number of people, they have the promise of anonymity and the ability to react either instantaneously or at a delay. She argues that this makes internet groups vastly different from traditional self-help (Sparks, 1992). Meanwhile, Howard Rheingold notes that the internet makes it possible to participate both in local, as well as international groups (Rheingold, 1993). King indicates that such groups offer a different kind of support, and a sense of belonging to a broader, virtual community. The benefits of such participation are quantifiable and complement traditional aid utilized in order to achieve and maintain abstinence (King, 1994). Suler points out that when using the internet, some people show more activity than in interpersonal contacts. He points to six factors which, together, create this disinhibiting effect. They are: dissociative anonymity, invisibility, asynchronicity, solipsistic introjection, dissociative imagination, and minimization of power (Suler, 2004). According to John Bargh and Katlny McKenna, the internet caused a breakthrough in personal communications. It is the internet that allowed a relative anonymity to its user, and the ability to organize group meetings with people of similar interests and values (Bargh \& McKenna, 2004). They highlight how participation and activity in appropriate virtual groups can become the basis for an individual's social life. Aza Baraka, Meyrana Boniel-Nissim and John Suler indicate that, in spite of the lack of clear data regarding the efficacy of online aid, research into the experiences of self-help groups shows that there are several factors, which can potentially affect the participants of such groups. Online support groups have, according to them, the goal of supporting and engendering good feelings, a sense of control, self-assuredness and independence, helping with social interactions and general improvement of the emotional sphere of participants (Barak et al., 2008).

The earliest research into internet self-help groups had been conducted in the first half of the 1990s. The results showed that such groups can, thanks to their informative and relational functions, as well as thanks to their emotional support function, play an important role in the recovery process of addicted persons (King, 1994). Storm King's research results showed that the regular contact with members of self-help groups through the internet can, in many ways, be conducive to maintaining narcotic abstinence. He stressed that nearly all of his respondents treated internet groups as complementary towards the ones happening "live" (King, 1994). In 2012, research was conducted over using internet self-help groups as a replacement for stationary ones in the sphere of psychic health (Townsend et al., 2012). The goal was to find the relationship between attitudes towards healing and factors such as scheduling and financial availability, stigmatization and the use of internet support. Four years later, Laura Lyytikäinen also conducted research of internet self-help groups for Alcoholics Anonymous in Russia. Results showed that it was a form of help more commonly used by women (Lyytikäinen, 2017). Małgorzata M. Owczarek's research (2018) also indicated that those groups are an important form of help for people addicted to psychoactive substances, and that their activity is conducted using social networks, blogs and internet fora. "Joining internet communities for addicted persons, and active participation in them is influenced by two factors: the ability of avoiding stigmatization in the virtual space, and openness characteristic to computer communication (Owczarek, 2018, p. 44). Main aspects of "communication through a computer device are anonymity, reduction of non-verbal and social markers, its ambiguous synchronous/asynchronous character, the existence of an internet audience and the so-called 'networking directed towards the I"" (Owczarek, 2018, p. 44).

The extent and characteristics of the population of addicted persons participating in internet groups is not exactly known. However, such groups are gaining in popularity, as confirmed by the aforementioned research by M. Owczarek. This is especially true contemporarily, when internet self-help groups are the participation mode 
available.

\subsection{Alcoholics Anonymous (AA) Community}

The Alcoholics Anonymous (AA) Community is one of the forms of self-help for persons suffering from alcohol use disorder (AUD). The first AA group in Poland was created in 1974. Currently, around 2800 such groups are holding meetings. The AA community program of recovery is laid out in the Twelve Steps programme, and the integrity of the community is maintained using the Twelve Traditions.

The proposed program is available for every alcoholic, regardless of their age, education, social status or religion (Woronowicz, 2009). AA group meetings can be closed (only for people addicted to alcohol) or open (anyone can participate). In some, anyone can speak (group meetings to discuss a chosen subject), or only certain, selected persons are supposed to share their experiences (so called speaker meetings). There are also group meetings devoted to the AA Steps, the AA Traditions, to reading the AA Great Book or Życie w trzeźwości [Living in Sobriety]. Meetings can also be focused towards beginners, towards providing information and organisational needs, or be held only for young alcoholics or only for women. In order to protect their social standing, special group meetings are also held for certain professional groups like doctors, lawyers or therapists, who want to avoid speaking of their problem in vicinity of their clients past and future (Woronowicz, 2020).

Among the differences between the participation in professional addiction therapy programmes and in the use of the Twelve Steps programme within the Alcoholics Anonymous community are that the AA community members take on full, individual responsibility for their process of recovery, that they take on and verify success at their own goals, and that their knowledge about alcoholism (alcohol addiction) comes from other members of the community and the community-approved literature. In contrast to professional psychotherapeutic meetings, participation in AA community meetings is not limited in duration and anyone can rely on it for as long as they want (Woronowicz, 2020).

\section{Research Methodology and Challenges}

This research is focused on the workings of AA groups during the COVID-19 pandemic (to be precise,: during its first few months). It had an exploratory character. It was conducted between the start of June and the start of July 2020. 225 people participated. The research was conducted using quantitative methods, using a questionnaire designed specifically for this purpose. The questionnaire consisted of 38 questions in total, including 5 respondents' particulars questions. All questions were closed, with a preselected cafeteria of responses to be selected by the respondents. In nine questions, respondents were allowed to select more than one response, and the remaining questions were all single-choice. The cafeterias used can be found in the tables containing research results below. Due to the particular character of the researched population, the "I do not want to respond to this question" option was added to every question. The frequency of this response is shown in the results and should not be treated as a lack of data, but a conscious choice on the side of the respondent to avoid the question. For the same reason, questions about the respondent's particulars were kept to a minimum, and only consisted of questions regarding gender, age, activity within the AA movement organisation, sponsors, and the stage of recovery in leaving the addiction. More questions of this kind could end up leading to resistance from the respondents, loath to give up their anonymity to participate in the research. For this reason, questions about place of inhabitation, localisation of one's AA group, or education were not asked. In the questionnaire, some scales and questions commonly used in the research on AA groups were used, such as the Cantril's Ladder, which used to measure the subjective sense of quality of life, taking the form of a simple eleven-point scale where 0 stands for "the worst the life can get" and 10 for "the best the life can get" (Wnuk, 2007). Another such example was a scale for measuring the progress alongside the Twelve Steps programme, to indicate on which stage of recovery the respondent is located (Mazur et al., 2009).

The research was conducted through an online method, which is the preferred choice under the pandemic conditions. To this end, Google forms were used. The invitation to research was directed using email to various Alcoholics Anonymous groups around Poland. The questionnaire link was made available through an internet page. The research was not conducted on a randomly selected, representative sample (as that would have been impossible during the pandemic). As such, the results should not be extrapolated onto the entire AA population. However, the authors believe that it provides a useful window into the situation of the AA groups during the first months of the COVID-19 pandemic, and signals important phenomena in the functioning of those groups, both for now, and for the post-pandemic future.

\section{Research Results}

The majority of the 225 person sample, consisted of men aged 40 to 59 , with a long experience in attending the AA 
community meetings (almost two thirds of the respondents have participated in those meetings for five years or more). Detailed demographic data can be found in table 1 .

Table 1. Overview of the respondents $(N=225)$

\begin{tabular}{ll}
\hline Gender & \\
man & $69.8 \%$ \\
woman & $30.2 \%$ \\
refused to respond & $0 \%$ \\
\hline Age & \\
$25-30$ years (no participant younger than 25) & $4.4 \%$ \\
$31-39$ years & $14.7 \%$ \\
$40-49$ years & $34.7 \%$ \\
$50-59$ years & $30.2 \%$ \\
$60-69$ years & $13.3 \%$ \\
70 years and more (oldest participant: 76 years) & $2.7 \%$ \\
\hline Duration of the AA groups attendance & \\
less than a year & $6.2 \%$ \\
a year to two & $8.9 \%$ \\
two to five years & $19.6 \%$ \\
five to ten years & $21.3 \%$ \\
more than ten years & $42.7 \%$ \\
difficult to say & $0.4 \%$ \\
refused to respond & $0.9 \%$ \\
\hline Source compiled by &
\end{tabular}

Source: compiled by own study.

Notably, a significant portion of the respondents was engaged and participated in the AA movement organisational services: almost half within their group, $15 \%$ in the intergroup level, and $21 \%$ in the upper levels $(8.4 \%$ regionally, $12.4 \%$ nationally). The research sample, therefore, consists of people more engaged with the AA community then an average meeting attendee, and who have attended those meetings for a longer time. Those conclusions are further confirmed by responses about the subjective appraisal of respondent's realized Twelve Steps. Over half of the respondents claim to have achieved the 12 th step, and only $15 \%$ found themselves at the start of the recovery (between steps 1 and 4). It should be noted that almost one fifth of the respondents (18\%) refused to answer the question, which is the highest refusal rate for the entire questionnaire.

\subsection{AA Meetings before the Pandemic}

Nearly all respondents $(96 \%)$ declared that before the 15th of March, 2020, their group meetings would occur on a weekly basis or more often, though they had not always attended them. $80 \%$ noted that their attendance was the same as the frequency of the meetings. An overwhelming majority of respondents $(88 \%)$ reported participating in meetings of groups beyond their own. No one reported negative emotions regarding group meeting participation, but three fourths reported very positive emotions. Attending group meetings was, for the majority of respondents, their main activity within the AA community. Beyond that, $58 \%$ reported meeting with their sponsor, and $24 \%$ participated in therapy under specialist/therapeutic guidance. For those having meetings with a therapist, over half of them would hold them often (once a week or more). $90 \%$ of those attending them rated them positively.

\subsection{What has the Pandemic Changed?}

According to the overwhelming majority of respondents (91\%), the pandemic caused a significant change in workings of AA group meetings, and only $4 \%$ reported no changes in this regard. The main change was the shift from real life to remote, online meetings. This happened to $90 \%$ respondents who noticed changes (that is $81 \%$ of all respondents). In $8 \%$ cases ( $7 \%$ of total respondents), meetings ceased to be held altogether. Two thirds (52\% of 
total respondents) whose meetings moved to online did not have to wait long for them - the first AA group meetings online happened for them already in march 2020 . One fifth (16\% of total respondents) had to wait for such meetings until April, and a few individuals (around 2\%) until May.

The number of organized meetings drastically increased. Almost three fourths (that is $64 \%$ of total respondents) declared that they would happen daily, and almost everyone else (aside from a few people who had issues responding to this question) pointed out that online meetings would be organized at least once or twice a week).

Almost half of respondents ( $42 \%$ of total respondents) who had their groups move to the internet ended up attending such meetings more than twice a week (including: 13\% daily, which is $11 \%$ of our total respondents). $39 \%$ (35\% of total respondents) attended them once or twice a week. Only a few (4\%) ended up connecting on a bi-weekly basis, and the remaining $4 \%$ even more rarely.

This increase in activity, however, did not translate into a higher level of satisfaction from participation in those AA group meetings. $81 \%$ online meetings participants ( $73 \%$ of total respondents) declared positive emotions with regards to them, but only in $48 \%$ cases ( $43 \%$ of our total respondents) those declarations were overwhelmingly positive. To compare, positive emotions regarding traditional AA group meetings before the pandemic were declared by $96 \%$ of respondents, including $75 \%$ overwhelmingly so.

Table 2. Positively appraised phenomena regarding the AA meetings online $(N=183)$

\begin{tabular}{ll}
\hline I could hear from new and interesting people who live far away from me & $75.4 \%$ \\
\hline I could attend the meetings more often & $50.3 \%$ \\
\hline I did not have to waste time commuting & $47.5 \%$ \\
\hline online meetings were attended by people who would not appear on live ones before & $47 \%$ \\
\hline it was easier to schedule & $43.2 \%$ \\
\hline some people would participate in online meetings more often than in live ones & $30.1 \%$ \\
\hline online meetings take less time & $25.1 \%$ \\
\hline I felt better in online meetings & $10.9 \%$ \\
\hline something else - responses do not fit into above categories & $10.6 \%$ \\
\hline it was easier for me to talk about my issues online & $9.3 \%$ \\
\hline I do not see any positives regarding online meetings & $5.5 \%$ \\
\hline
\end{tabular}

Source: compiled by own study.

Participation in online AA group meetings was positively appraised by our respondents mostly because they allowed them to meet new people, who would otherwise be difficult to come by. Other, significant positive aspects: the ability to attend group meetings more often, less time wasted on commute, the appearance of new people in the meetings and easier scheduling. Those positives were indicated by half (or a little less than half) of people responding to the question. Remaining positive aspects were indicated by a lesser portion of people participating in the online AA group meetings. 
Table 3. Negatively appraised phenomena regarding the AA meetings online $(N=183)$

\begin{tabular}{lc}
\hline I felt better in live meetings & $43.2 \%$ \\
\hline some people stopped showing up on online meetings & $36.1 \%$ \\
\hline some people would attend online meetings more rarely than live ones & $26.2 \%$ \\
\hline this form of contact did not encourage me to engage & $25.7 \%$ \\
\hline connectivity issues & $18.6 \%$ \\
\hline this form of contact felt artificial & $16.9 \%$ \\
\hline I could not attend as often I wanted to & $3.8 \%$ \\
\hline meetings online take more time & $1.6 \%$ \\
\hline scheduling was more difficult & $0.5 \%$ \\
\hline something else(including: breaches of anonymity: $1.0 \%)$ & $5.1 \%$ \\
\hline I do not see any negative phenomena regarding online meetings & $25.1 \%$ \\
\hline
\end{tabular}

Source: compiled by own study.

Discomfort emerged as the primary flaw of online AA meetings. Nearly half of respondents who participated in such meetings claimed feeling more comfortable during live ones. It was also indicated that some people started showing up more rarely during meetings, or stopped altogether, which drives disengagement. However, a fourth of respondents did not see any faults in online AA meetings.

Responding to the question about positive or negative aspects of online AA meetings, respondents were allowed to pick any number of responses from the list. The more were selected, the more in-depth their appraisal (negative or positive) was. It should be noted that the positive phenomena were indicated more often than the negative ones. Respondents selected an average of 3.5 positives (out of 10 possible), and an average of 1.8 negatives (likewise out of ten).

Table 4. The benefits of attending AA meetings before and during the pandemic (as online meetings) $(N=225)$

\begin{tabular}{lll}
\hline All differences are significant except one (see below) & Before the pandemic & During the pandemic \\
\hline a sense of community and contact with fellow alcoholics & $83.9 \%$ & $72 \%$ \\
a drive to personal development & $75.8 \%$ & $46.2 \%$ \\
a direct contact with a fellow alcoholic and being supported by them & $72.6 \%$ & $33.8 \%$ \\
learning to listen to others & $65.9 \%$ & $53.8 \%$ \\
acquiring a realistic self-image & $59.6 \%$ & $20.9 \%$ \\
friendships within the group & $57.4 \%$ & $28.9 \%$ \\
candor and honesty from others & $57 \%$ & $38.2 \%$ \\
shared experiences & $49.3 \%$ & $37.3 \%$ \\
learning behaviours and attitudes & $44.4 \%$ & $22.7 \%$ \\
building self-respect & $39.5 \%$ & $19.6 \%$ \\
learning to name emotions and feelings & $39 \%$ & $23.1 \%$ \\
acquiring a sense of hope (not significant difference) & $36.8 \%$ & $29.8 \%$ \\
the ability to be accepted by others & $34.5 \%$ & $16.4 \%$ \\
no response & $1 \%$ & $8 \%$ \\
hard to say & $0 \%$ & $11.1 \%$ \\
\hline Source: comp & & \\
\hline
\end{tabular}

Source: compiled by own study.

The decrease in satisfaction when attending online AA meetings organized during the pandemic is also visible in 
the subsequent question. Our respondents were asked to indicate benefits they gained from attending AA meetings before the 15th of March 2020. At the end of the questionnaire, they were also asked an analogous question about benefits from attending meetings online during the pandemic. Similarly to the previous question, they were allowed to pick any number of responses from the list. The more they selected, the more benefits to attending in one way or another they claimed. Respondents pointed to more benefits from attending meetings live, than online during the pandemic (average of 7.2 to 4.4 out of 13 possible). Furthermore, in the question about the "traditional" meetings no one selected the "hard to say" response, and only $1 \%$ of respondents did not provide any response. Meanwhile, regarding online meetings, $11 \%$ of respondents selected the "hard to say" response, and $8 \%$ selected none. We can thus say that almost one fifth of our respondents did not indicate a single benefit to the online AA meeting format.

Comparing individual benefits between "traditional" and "on-line" meetings shows that in all cases, they were selected fewer times when online. The biggest differences (comparing the percentage of selections for the pre-pandemic and pandemic situation) was in regards to the benefit of having contact with a fellow alcoholic and the ability to be supported by them, as well as in regards to the benefit of acquiring a realistic self image. In both cases, the rate of selection dropped by $39 \%$ percentage points. In percentage terms, bigger losses were suffered by the latter benefit. Acquiring a more realistic self-image was selected as a benefit by two thirds less respondents compared to "traditional" meetings (the analogous rate for direct contact with a fellow alcoholic is 53.4\%). Smallest losses were recorded regarding gaining a sense of hope ( 7 percentage points fewer, $19 \%$ fewer selections) and the sense of community and contact with fellow alcoholics (almost 12 percentage points less, and $14.2 \%$ fewer selections).

Chief benefits of attending AA meetings turned out to be pretty constant, however, regardless of the form the meetings take. They are: the sense of community and contact with fellow alcoholics, the drive to self-development, direct contact with a fellow alcoholic and being supported by them, and learning to listen to others. The shift to online meetings decreases the subjective sense of benefitting from the contact with the fellow alcoholics. Virtual contacts did not provide, according to many respondents, the same kind of support as direct forms.

Table 5. Preferences for post-pandemic AA meetings $(N=225)$

\begin{tabular}{lc}
\hline only live meetings & $21.3 \%$ \\
\hline mainly live meetings, sometimes complemented by online ones & $66.2 \%$ \\
\hline mainly online meetings, sometimes complemented by live ones & $7.1 \%$ \\
\hline only online meetings & $0.9 \%$ \\
\hline no opinion, I will fit in with the will of the majority & $2.7 \%$ \\
\hline hard to say & $1.3 \%$ \\
\hline refuse to respond & $0.4 \%$ \\
\hline
\end{tabular}

Source: compiled by own study.

It shouldn't be then a surprise that the experiences from online AA meetings suggest that this form will not replace live meetings. However, it can usefully and conveniently complement them. Two thirds of our respondents think that after the pandemic is over, meetings should take place in their "traditional", live form, which could sometimes be complemented through online meetings. The tendency to "traditional" meetings can also be seen in how a fifth of our respondents rejected the possibility of on-line meetings in the future, while only $8 \%$ prefers online meetings (and only $1 \%$ would want to move meetings online altogether).

While the pandemic has not negatively influenced AA meetings attendance, or even increased it, the decrease in the use of therapies guided by a professional specialist/therapist is notable. Before the pandemic, a fourth of our respondents used this form of support, while after the 15th of March 2020, that dropped to barely $10 \%$. Those who kept using specialist/therapist help tended to meet with the therapist as often as before, but using remote tools: mainly the internet, sometimes phone. Positive aspects of this new form of contact were seen mainly in the organisational side (time saving, easier scheduling), and negative ones in the sense of lesser engagement and artificiality of such contact.

However, the group of people contacting their sponsor increased. $72 \%$ of our respondents have a sponsor, but 
before the pandemic only $59 \%$ was meeting with them ( $78 \%$ of respondents who had a sponsor at all). During the pandemic, $66 \%$ of our respondents contacted their sponsor $(89 \%$ of respondents who had one at the time of this research). It was usually phone contact ( $60 \%$ of our respondents), more rarely the internet $(23 \%)$ or personal $(16 \%)$.

\subsection{How the Pandemic Affected the Respondents}

Nearly $95 \%$ of our respondents claimed to uphold abstinence during the pandemic, while the rest either confessed to returning to alcohol during the pandemic, or refused to answer the question (which does not have to indicate a breach of abstinence). The overwhelming majority of respondents who broke it were on the heels of a very short period without alcohol (less than a year). Among respondents who broke it during the pandemic, none had been in abstinence for longer than 5 years.

The pandemic, at least at the time of research (June 2020) did not have a definitive influence on the quality of life of our respondents (as indicated by Cantril's Ladder described above). For almost half (46\%) the life was the same as it was before the pandemic. Furthermore, nearly a third of our respondents (31\%) said that their life was better than before the pandemic. The reverse appraisal, that it was worse than before, was given by $23 \%$ of our respondents. In effect, average appraisal of life during the pandemic (in June 2020) was slightly higher than their appraisal of life before the pandemic, as the respondents remembered it (7.7 to 7.5).

\section{Discussion}

The majority of existing research [Barak, Boniel-Nissim, Suler, Bargh, McKenna] showcases the potential for internet self-help groups which, increasingly, are becoming an alternative place to look for support in dealing with life's problems. Such groups are significant among the help available to people addicted to psychoactive substances. The desire to avoid social stigma is the chief factor in deciding to participate in such groups [Owczarek, Townsend, Gearing, Polyanskaya, Lyytikäinen]. Research thus far, however, has mainly pertained to groups created within the internet environment, and remaining there by choice. Our research deals with a situation where contact had initially been made in real life and moved online due to external factors beyond the control of group organizers.

The research results indicate that the COVID-19 pandemic affected almost all of our respondents. The way the AA meetings work changed. For four fifths of our respondents, meetings moved online relatively quickly, already in March. Few had to wait until April, fewer still until May. However, for $7 \%$ of our respondents, the pandemic led to a suspension of group activity. Their groups did not move online, and the meetings were put on hold.

Compared to live meetings, the frequency of meetings increased, as did the intensity of participation by our respondents. However, the satisfaction from participation simultaneously decreased. Major flaws of online meetings are seen in the discomfort of respondents (as some of them feel better during live meetings), and in the fact that some people stopped attending meetings after they moved to the internet. Our respondents also had the sense that online meetings benefitted them less compared to "live" ones, especially with regards to direct contact with a fellow alcoholic and the ability to receive support from them. The positive sides of online meetings mainly had to do with the possibility of meeting and contacting new, interesting people living far from the respondent, and with organisational matters (less time spent, easier scheduling, etc.).

The frequency of attending therapy with specialists/therapists decreased during the pandemic, while the frequency of contact with one's sponsor increased.

The overwhelming majority of respondents declared that they did not break abstinence during the pandemic. Those who did were usually people who had spent little time (usually a year, five years at most) in abstinence.

The pandemic did not influence subjective appraisal of life quality. The average appraisal increased slightly from 7.5 to 7.7 .

\section{Conclusions}

While internet groups are a widespread way of delivering help, and aspects of cyberspace such as anonymity and ease of access lead to a greater openness than in traditional forms of communication (Owczarek 2018), our research showed that after the pandemic, our respondents would prefer to return to traditional, live AA meetings, organized as they used to be before COVID-19. Online meetings would only serve a useful, but ultimately complementary role. As such, it should not be expected that the internet groups will replace AA meetings at a greater scale.

The pandemic situation is unprecedented, and as such our research provides new data, drawing a wide field for future study, both during the pandemic, and after it is over. 


\section{Competing Interests Statement}

The authors declare that there are no competing or potential conflicts of interest.

\section{References}

Barak, A., Boniel-Nissim, M., \& Suler, J. (2008). Fostering empowerment in online support groups. Computers in Human Behavior, 24, 1867-1883. https://doi.org/10.1016/j.chb.2008.02.004

Bargh, J. A., \& McKenna, K. Y. A. (2004). The internet and social life. Annu Rev Psych, 55, 573-90. https://doi.org/10.1146/annurev.psych.55.090902.141922

BORIS. (2020). Samopomoc [Self-help]. Retrieved June 8, 2021, from http://samopomoc.boris.org.pl/o-samopomocy/grupysamopomocowe/

Chodkiewicz, J. (2020). Extracts from speeches. Retrieved from https:/pulsmedycyny.pl/covid-19-a-uzaleznienia-jak-epidemia-wplynela-na-spozycie-alkoholu-992302

$\begin{array}{llllll}\text { Johnson, } & \text { S. } & \text { Retrieved } & \text { February } & 25, & 2021,\end{array}$ https://khn.org/news/drinking-surged-during-the-pandemic-do-you-know-the-signs-of-addiction/

Juros, A. (2003). Zasada pomocniczości - wspieranie działań samopomocowych i samoorganizacyjnych [Principle of subsidiarity - promoting self-help and self-organisation]. In P. Jordan (red.), Od pomocy do samopomocy [From assistance to self-help]. Warszawa: Centrum Wspierania Aktywności Lokalnej CAL.

Kawula, S. (2005). Czynniki i sieć wsparcia społecznego w życiu człowieka[Factors and network of social support in human life]. In: S. Kawula (ed.), Pedagogika społeczna. Dokonania - aktualność - perspektywy [Social Pedagogy. Achievements - topicality - perspectives]. Toruń: Wydawnictwo Adam Marszałek.

King, S. A. (1994). Analysis of electronic support groups for recovering addicts. Interpersonal. Computing and Technology: An Electronic Journal for the 21st Century, 2(3), 47-56.

Knoll, N., \& Schwarzer, R. (2007). Functional roles of social support within the stress and coping process: A theoretical and empirical overview. International Journal of Psychology, 42(4), $243-252$. https://doi.org/10.1080/00207590701396641

Lakey, B., \& Cohen, S. (2000). Social support theory and measurement. In S. Cohen, L. G. Underwood, \& B. H. Gottlieb (eds.), Social support measurement and interventions: A guide for health and social scientists (p. 29-52). New York: Oxford. https://doi.org/10.1093/med:psych/9780195126709.003.0002

Lyytikäinen, L. (2017). Mutual support and recovery in the Russian Alcoholics Anonymous online community. Nordic Studies on Alcohol and Drugs, 33(2), 151-172. https://doi.org/10.1515/nsad-2016-0013

Mazur, J., Małkowska-Szkutnik, A., Oblacińska, A. \& Kołoło, H. (2009). Drabina Cantrila w badaniach stanu zdrowia i nierówności w zdrowiu uczniów w wieku 11-18 lat [Cantril's ladder in the study of health status and health inequalities in students aged 11-18 years]. Problemy Higieny i Epidemiologii, 90(3), 355-361.

Nahid, O. W., \& Sarkis, E. (1994). Types of social support: relation to stress and academic achievement among prospective teachers. Canadian Journal of Behavioral Science, 26(1), 1. https://doi.org/10.1037/0008-400X.26.1.1

Owczarek, M. M. (2018). Internetowe grupy wsparcia jako forma pomocy dla osób uzależnionych od substancji psychoaktywnych [Internet support groups as a form of help for substance abuse]. Warszawa: Wydział Stosowanych Nauk Społecznych i Resocjalizacji. Uniwersytet Warszawski, 2018. Unpublished doctoral dissertation

Pollard, M. S., Tucker, J. S., \& Green, H. D. (2020). Changes in Adult Alcohol Use and Consequences During the COVID-19 Pandemic in the US. Research Letter Substance Use and Addiction. https://doi.org/10.1001/jamanetworkopen.2020.22942

Rheingold, H. (1993). Cold Knowledge and Social Warmth. Newsweek, September, 6.

Riesseman, F. (1996). Understanding the Self-Help Organization (Book). Addiction, 91(6), 887.

Schwarzer, R., \& Weiner, B. (1991). Stigma Controllability and Coping as Predictors of Emotions and Social Support. Journal of Social and Personal Relationships, 8(1), 133-140. https://doi.org/10.1177/0265407591081007

Sęk, H., \& Cieślak, R. (2011). Wsparcie społeczne - sposoby definiowania, rodzaje i źródła wsparcia, wybrane koncepcje teoretyczne [Social support - ways of defining, types and sources of support, selected theoretical 
concepts]. In: H. Sęk, R. Cieślak R (ed.), Wsparcie spoleczne, stres $i$ zdrowie [Social support, stress and health]. Warszawa: Wydawnictwo Naukowe PWN.

Sparks, S. N. (1992). Exploring Electronic Support Groups. American Journal of Nursing, 62. https://doi.org/10.2307/3426882

Suler, J. (2004). The Online Disinhibition Effect. CyberPsychology \& Behavior, 7(3), 321-326. https://doi.org/10.1089/1094931041291295

Szmagalski, J. (1994). Teoria pracy socjalnej a ideologia i polityka społeczna: przyktad amerykański [Social work theory versus ideology and social policy: the American example]. Warszawa: Wydawnictwo Uniwersytetu Warszawskiego.

Townsend, L., Gearing, R. E., \& Polyanskaya, O. (2012). Influence of Health Beliefs and Stigma on Choosing Internet Support Groups Over Formal Mental Health Services. Psychiatric Services, 63(4), 370-376. https://doi.org/10.1176/appi.ps.201100196

Włodarczyk, E. Zakończenie: O wsparciu społecznym i jego znaczeniu [On social support and its importance], Retrieved from https://repozytorium.amu.edu.pl/handle/10593/15638

Wnuk, M. (2007). Duchowy charakter Programu Dwunastu Kroków a jakość życia Anonimowych Alkoholików [The spiritual nature of the Twelve Step Programme and the quality of life in Alcoholics Anonymous]. Alkoholizm i Narkomania, 20(3), 289-301.

Woronowicz, B. T. (2009). Uzależnienia. Geneza, terapia, powrót do zdrowia [Addictions. Genesis, therapy, recovery]. Poznań, Warszawa: Media Rodzina i Parpamedia.

Woronowicz, B. T. (2020). Dziedzictwo psychiatrii $i$ psychologii w Programie Wspólnoty Anonimowych Alkoholików [The Legacy of Psychiatry and Psychology in Alcoholics Anonymous], Alkoholizm i Narkomania/ Alcoholism and Drug Addiction, Instytut Psychiatrii i Neurologii. Approved for publication: 27.05.2020.

\section{Copyrights}

Copyright for this article is retained by the author(s), with first publication rights granted to the journal.

This is an open-access article distributed under the terms and conditions of the Creative Commons Attribution license (http://creativecommons.org/licenses/by/4.0/). 